\title{
Mini-Thixoforming of Low-Carbon High-Alloy Steel
}

David Aisman, Hana Jirkova, Katerina Rubesova, Stepan Jenicek

Regional Technological Institut, University of West Bohemia 8, 30614 Plzen, Czech Republic, E-mail: daisman@vctt.zcu.cz, hstankov@vctt.zcu.cz, krubesov@vctt.zcu.cz, jeniceks@vctt.zcu.cz

Semi-solid processing allows novel microstructures to be produced even in conventional materials. This is thanks to the peculiar conditions of the process and the rapid solidification. Despite that, semi-solid processing is not widely used in practice due to its technological complexity. Mini-thixoforming is an innovative method of processing metals in the region between their solidus and liquidus temperatures. With its small volume of the metal feedstock, it is a very precise and highly dynamic process. Consequently, it can be employed for materials with a very narrow freezing range which, until now, were impossible to thixoform conventionally. The present experiment focused on one of such materials: the low-carbon high-alloy age-hardenable X5CrNiCuNb16-4 steel. Owing to the low carbon level, the relevant temperature interval was $1380-1420{ }^{\circ} \mathrm{C}$ which, together with the need for strict control, posed a technological challenge. Once the semi-solid processing parameters were optimized, the die cavity was filled as required and the final products showed good surface quality. The resulting single-phase microstructure consisted of ferrite. Hence, given the $17 \%$ level of dissolved chromium, there is a potential for excellent corrosion resistance and, possibly, for subsequent age hardening of the material

Keywords: Mini-thixoforming, semi-solid state, $\mathrm{X} 5 \mathrm{CrNiCuNb} 16-4$ steel, single-phase structure

\section{Acknowledgement}

This paper includes results created within the project LO1502 Development of Regional Technological Institute. The project is subsidised by the Ministry of Education, Youth and Sports from specific resources of the state budget for research and development.

\section{References}

[1] CEZARD, S. P. (2008). Thixoforming of Steel: A state of the Art from an Industrial Point of View, Proceedings of the 10th International Conference on Semi-Solid Processing of Alloys and Components, pp. 641-646, ISBN: 3908451-59-0, Aachen

[2] FLEMING, M. C. (1991). Behavior of metal alloys in the semisolid state, Metallurgical Transactions A, Vol. 22, pp. $957-981$

[3] MIDSON, S. P., NICHOLAS, N. H., NICHTING, R. A., YOUNG, K. P. (1992). Semi-solid forming high temperature alloys. In the 2nd International Conference on the Processing of Semi-Solid Alloys and Composites; pp 140148. Edited by Brown SB, Flemings MC. Cambridge, MA, USA.

[4] HIRT, G., BLECK, W., BÜHRIG-POLACZEK, A., SHIMAHARA, H., PÜTTGEN, W., AFRATH. C. (2006). Semi Solid Casting and Forging of Steel., Solid State Phenomena, Vols. 116-117, pp. 34-43.

[5] http://congress.cpb.de/2/fileadmin/user_upload/MAIN-bilder/ifc2014/27_R\%C3\%A9gis_Bigot_Bastien0107.pdf (accessed on 20 Nov. 2014)

[6] HIRT, G., KOPP, R. (2009). Thixoforming: Semi-solid Metal Processing, ISBN: 978-3-527-32204-6, Germany

[7] (2013). Semi-Solid Processing (SSP) of Alloys: Part Two, Total material

[8] AIŠMAN, D., JIRKOVÁ, H., MAŠEK, B. (2009). Forming Technology of Small Parts in Semi-solid State, in: Proceedings of the 20th International DAAAM Symposium Intelligent Manufacturing \& Automation: Theory, Practice \& Education, Vol. 20, No. 1, pp. 1895-1896, ISSN 1726-9679, ISBN 978-3-901509-70-4

[9] RONEŠOVÁ, A., MAŠEK, B. (2009). Digital Generator of Phase Shift Modulation Patent USA, No. 7,480,155

[10] MAŠEK, B., AIŠMAN, D., RUBEŠOVÁ, K., JIRKOVÁ, H. (2014). Semi-Solid Processing of Powder Steels in Cryogenically-Cooled Die, Materials Science Forum. vol. 783-786, pp. 801-806.

[11] JMatPro, Release 7.0, Sente Software Ltd., 2013

[12] SEN, I.; JIRKOVA, H.; MASEK, B.; BÖHME, M.; WAGNER, M. F.-X. (2012). Microstructure and Mechanical Behavior of a Mini-Thixoformed Tool Steel, Metallurgical and Materials Transactions, pp. 3034 - 3038 
[13] MAŠEK, B., JIRKOVÁ, H., AIŠMAN, D. (In print), Effect of Initial Microstructure on Properties of Low-Alloyed Steel upon Mini-Thixoforming, Materials and technology

[14] BRYKSÍ STUNOVÁ, B., BRYKSÍ, V. (2015). Phase Segregation during Processing of Semi-Solid Slurry by Rheocasting Method SEED, Manufacturing Technology, Volume 15, No. 4, pp515-520, ISSN 1213-2489

[15] KUČEROVÁ L., ZETKOVÁ I (2016). Metallography of 3D Printed 1.2709 Tool Steel. Manufacturing Technology, Volume 16, No. 1, pp.140-144, ISSN 1213-2489

\section{Paper number: M2016156}

Copyright @ 2016. Published by Manufacturing Technology. All rights reserved. 